\title{
POSITION
}

\section{UD I VERDEN}

Antropologi, etik og formidling

\section{ANJA MARIE BORNØ JENSEN}

Denne Position tager udgangspunkt i formidlingen af antropologisk forskning og argumenterer i tråd med temanummerets agenda for, at de etiske overvejelser ikke er forbeholdt planlægningen og udførelsen af et studie, men snarere accelererer og kompliceres i formidlingen af resultaterne i forskellige fora, når antropologien skal ud i verden. De positioner, antropologen bevidst eller ubevidst indtager i sin formidlingspraksis, kræver en særlig etisk refleksion, som jeg vil diskutere med udgangspunkt i min egen forskning og formidling i organdonationsfeltet. På baggrund af de konkrete etiske udfordringer, jeg har mødt i formidlingen af forskningsresultaterne til mine informanter, i akademia og i medierne, opfordrer jeg til, at antropologen fortsætter de etiske refleksioner og diskussioner forbi metode og analyse på vejen ud i formidlingens bakkede og uendelige landskab. Dermed tilslutter jeg mig ideen om konstant etisk refleksion og stillingtagen i antropologisk praksis (Armbruster 2010; Hastrup 2009).

I antropologiske publikationer og opgaver har forskningsetiske overvejelser ofte deres plads et sted efter metodeafsnittet. Omdrejningspunktet er, hvordan der rekrutteres, informeres og anonymiseres i henhold til gældende regler. Når der tales om forskningsetik, gælder det om at sikre sig, at den forskning, man bedriver, ikke kommer nogen til skade. Forskeren må derfor på overbevisende måde argumentere for, at alt er gået rigtigt til i planlægningen og udførelsen af studiet, og vise en evne til at håndtere og reflektere over de særlige situationer og vilkår, feltstudiet kræver (McLean \& Leibing 2008). Omstændigheder forandrer sig ikke, fordi der er sat punktum for feltnoterne, og antropologen har forladt stedet og påbegyndt det analytiske arbejde frem mod det skrevne produkt. Relationerne afbrydes som bekendt ikke trods feltarbejdets tidslighed (Hastrup 2003), men de tager en ny form $i$ informanternes forvandling fra generøse værter til interesseret publikum og i forskerens forvandling fra undrende gæst til konkluderende vidensleverandør. De etiske overvejelser i formidlingen skærpes, når 
antropologen bevæger sig i emnefelter, der anses som kontroversielle eller omdiskuterede og er under stor mediebevågenhed. Eller i felter, der har en eksplicit forventning om klare holdningstilkendegivelser, en brugbar evaluering eller en bevidst intervention. Spørgsmålet er, hvordan vi som antropologer formår at tænke etikken ud i verden. Når jeg i denne Position diskuterer etik i forskningsformidlingen, er det ikke kun for at se det gode analytiske potentiale i, hvorledes forskningsresultaterne modtages og fortolkes. Det er også for at opfordre til, at de udfordringer, antropologien møder, efter konklusionen er skrevet, deles og diskuteres blandt kolleger.

\section{„Du kan hilse og sige ..." - det lyttende mellemled?}

Når man som antropolog får en midlertidig, men stærk relation til de mennesker, man undersøger, forpligter man sig ofte også på at levere resultaterne tilbage i en eller anden form eller orientere dem om, hvad projektet ender med. I mit tilfælde har jeg oplevet, at pårørende, der har stået med spørgsmålet om organdonation, har et stærkt ønske om, at jeg bliver et mellemled mellem dem og de afdelinger, hvor de tog deres beslutning. Antropologen forpligter sig altså ikke kun på en bred formidling af nogle forskningsresultater, men på en decideret overlevering af erfaringer til et ganske bestemt publikum.

Jeg har talt med mange familier, der ud over at dele deres erfaringer i forskningsøjemed har en klar formodning om, at de ved at bidrage til mine projekter kan lave en slags fremtidig investering i kommende donorpårørendes velbefindende. De fortæller om, hvad de støttede sig op ad i beslutningen, om små overfyldte pårørenderum, vigtigheden af at få tilbudt kaffe og mad, behovet for enestue til patienten, dialogen med personalet, afskeden med afdøde, vigtigheden $i$ at se sit familiemedlem igen efter organudtagningen og meget andet. Fortællingerne er fulde af både taknemmelighed over omsorgen og kritik af forhold, der var uacceptable og kan forbedres. At medvirke i et antropologisk forskningsprojekt med tanke på de kommende familier, der kan drage nytte af de erfaringer, man har gjort sig, kan anses som et element af familiers håbspraksis, der strækker sig ud over organmodtagernes overlevelse og organdonorens meningsfulde eftermæle (Jensen 2016). Nogle familier giver endda konkrete råd til, hvordan personalet kan få flere familier til at sige ja. Når antropologen bliver bedt om at „hilse og sige på afdelingen“, vedrører det altså både håb om bedre pårørendeomsorg og håb om flere tilgængelige organer.

Som mange antropologiske kolleger kan nikke genkendende til, er det altså et slags etisk imperativ i min felt, at konklusioner om informanternes vilkår ikke kun skal eksistere i akademia, men også komme ud i verden og være med til at 
forbedre nogle vilkår for en marginaliseret gruppe. Det forvandler antropologen til en slags lyttende mellemled. Lyttende, fordi vi oftest har god tid, og fordi vi i overensstemmelse med vores metodologiske overvejelser giver masser af tid til, at informanterne selv kan italesætte deres erfaringer. Mellemled, fordi vi i kraft af vores projekter bliver en forbindelse til dem, der ,kan gøre noget“ - i mit tilfælde til de læger og sygeplejersker, der står med familierne, og som potentielt kan forbedre den omsorg, kommunikation og de forhold, familierne møder. For mit vedkommende føler jeg af respekt for de familier, jeg undersøger, derfor en stor forpligtelse til at prøve at videreformidle deres stemmer i debatten, i personaleundervisning og i det politiske arbejde. Dette engagement er kendetegnende for meget antropologisk forskning; resultaterne lever, bruges og tages alvorligt i de felter, hvor de er skabt, og indtænkes i udviklingsarbejdet.

Med forbehold for en uforholdsmæssig sammenligning er dette stigende samfundsengagement og konkrete forbedringer i informanternes liv i tråd med, hvad Iain Wilkinson og Arthur Kleinman opfordrer til i deres nye bog A Passion for Society (2016), hvor de opfordrer samfundsvidenskaberne til større politisk engagement og menneskelig involvering og omsorg. Jeg har tit spurgt mig selv, om jeg har gjort det godt nok over for mine familieinformanter, der har investeret så meget ved at medvirke. Hvorfor har jeg ikke selv startet en forening for donorpårørende, når nu jeg konstant på skrift og fra talerstole undrer mig over, hvorfor en sådan omsorgsfuld forening ikke findes?

Alene udvælgelsen af fortællinger i publikationer volder som bekendt ofte problemer for antropologer og kan medføre overvejelser, om vi ,gør det godt nok“. En ældre dame, der mistede sin mand, fik som alle andre af mine informanter tilsendt min afhandling og valgte at ringe tilbage til mig for at kommentere på den. Hendes opkald gjorde mig nervøs, da hendes historie ikke var nævnt på nogen måde i afhandlingen. Men hun roste mig for at beskrive præcis, hvordan det havde føltes for hende. Formidlingen var sådan set lykkedes, hun følte sig set og hørt, men det gjorde mig alligevel bevidst om brugen af ,yndlingsinformanter“ og min implicitte strategi om at bruge historier fra pårørende til yngre donorer for at understrege chokket og smerten ved et pludseligt tab. Det bliver altså også en etisk overvejelse for antropologen, at vi bevidst eller ubevidst udvælger de „bedst sælgende“ informanter i vores formidling.

\section{„Hvad har du fundet ud af?“ - den leveringsdygtige problemløser?}

I antropologisk forskningsetik har der været stigende fokus på, at etikken bør anses som et kontekstuelt forhold, hvori antropologen må navigere og tilpasse sig for ikke at overskride lokale grænser (Hastrup 2009; Høyer et al. 2011; Jensen 2009). 
Hver felt, antropologen betræder, har sine helt egne uskrevne regler, moralske kodeks og særlige natur, der må afkodes for ikke at træde ved siden af. Det har jeg selv stiftet bekendtskab med i mit feltarbejde på neurointensive afdelinger, hvor jeg deltog i samtaler med pårørende, der skulle have beskeden om, at deres familiemedlem ikke ville overleve, og dermed tage stilling til organdonation. Mit emnemæssige fokus på organdonation kunne ikke kommunikeres efter gældende etiske forskrifter før samtalen eller i selve situationen, da min dagsorden og motivation for at være i samtalerummet (nemlig mulig organdonation) ville være en klodset dødsdom til pårørende, der stadig havde håb om deres familiemedlems overlevelse (Jensen 2011). Denne etiske balancegang, som jeg aldrig ville have mestret uden mit gode samarbejde med læger og sygeplejersker, gav mig analytisk indsigt $i$ vigtigheden af dødens timing og orkestrering $i$ organdonationssamtaler (ibid.) og bekræfter derfor den tendens, der også har været genstand for antropologisk opmærksomhed, nemlig at der er stort analytisk potentiale i de etiske udfordringer. Ofte er det der, hvor det bliver støjende, farligt eller potentielt problemfyldt, at det analytiske gods befinder sig, og forskerens egne reaktioner tjener derfor ofte som værdifuldt analytisk kompas i den undertiden nådesløse vej til de analytiske gennembrud (Jensen 2009).

I løbet af mit 14 måneders feltarbejde på neurointensive afdelinger, hvor jeg studerende praksis i donationsforløb og pårørendesamtaler, blev jeg meget ofte spurgt, hvad jeg så havde fundet ud af. Dette spørgsmål blev stillet under lange nattevagter eller i kaffepauser, hvor der var tid til at sende antropologens mange spørgsmål den modsatte vej og spørge ind til de familier, man som læge eller sygeplejerske kun mødte i korte tragiske forløb og sjældent havde mulighed for at følge op på. Hvad tænker de, hvad skal vi gøre anderledes, og hvordan kan vi få flere til at sige ja? Selv om min agenda for organdonationsforskning aldrig har været at skaffe flere organer til et land som Danmark, hvor raterne er lave, selv om den offentlige accept er stor (Nordfalk et al. 2016), er ønsket om bedre og flere donationsforløb en præmis, man ikke kan overse.

Det etiske spørgsmål for mig har ikke så meget været, om jeg skulle videregive familiernes erfaringer til de involverede læger og sygeplejersker, men snarere hvad deres interesse var baseret på. Er det, fordi de ønsker at blive bedre til pårørendeomsorg, eller er det, fordi de ønsker at få flere familier til at sige ja og få flere organer? Og vil dette i så fald være forkert af mig at bidrage til? Efter et årtis forskning om danske pårørende ligger jeg inde med mange bud på, hvordan pårørendeomsorgen kan forbedres, men jeg er også fuldstændig klar over, hvordan man kan gribe et donationsforløb an, så der er størst chance for, at familien siger ja. Mit oprindelige udgangspunkt om ikke at være interesseret $i$ at få flere tilgængelige organer presses en smule af de gældende vilkår, jeg møder 
for min formidling, hvor både personale, medier og selv pårørende (uanset om de siger ja eller nej) er interesserede i, at Danmark bliver bedre til organdonation. Til gengæld betvivler jeg ikke personalets dedikation til at agere omsorgsfuldt uanset familiens svar. På en medicinsk konference i Sverige kom en ledende sygeplejerske hen til mig og sagde, at hun havde hørt mig for tre år siden og var gået hjem på afdelingen og havde implementeret nogle af de ting om pårørendeomsorg, jeg havde anbefalet. Og det virkede, sagde hun. Jeg blev utrolig glad og takkede og blev så inderligt taknemmelig for at lave forskning, der ikke kun blev opgjort $\mathrm{i}$ BFI-niveauer (Den Bibliometriske Forskningsindikator) og impact factor (JIF, Journal Impact Factor) og citationer, men rent faktisk kunne hjælpe nogen. Jeg har senere overvejet, om hun mon mente, at de var blevet bedre til pårørendeomsorg baseret på mine fund, eller om de var blevet bedre til at få pårørende til at sige ja til organdonation baseret på mine fund. Det ene udelukker ikke det andet. Jeg håber på det første, men jeg skammer mig ikke over det sidste.

\section{„Er det virkelig så rosenrødt?" - den ukritiske feltkæledægge?}

„Er det virkelig så rosenrødt, som du beskriver,“ spurgte en ældre kvindelig professor for nylig på en konference i England, hvor jeg fremlagde mine fund om pårørende til organdonorer. Jeg havde beskrevet vigtigheden af, at donorernes kroppe blev behandlet med respekt, og jeg havde talt om håb, skyld og tvivl i familiernes erfaringer med hjernedøden. Derudover havde jeg talt om nødvendigheden af at synliggøre og ritualisere dødstidspunktet med ord, billeder og handlinger, idet denne teknologiske død, hvor hjertet stadig banker, og kroppen er varm, kan virke svær at forstå for familier i chok. En sådan ritualisering (Bell 1992), hvor personalet tilpasser afskeden efter familiens særlige situation og behov, kan betyde, at familier forstår dødstidspunktet bedre, og beslutningen om organdonation opleves som mere meningsfuld (Jensen 2011). Jeg havde ikke fremstillet læger og sygeplejersker som ivrige organhøstere, tværtimod havde jeg formidlet, hvordan mange af deres skrupler og udfordringer er de samme som familiens, på trods af deres forskellige positioner. Jeg havde heller ikke - som mange andre forskere i mit felt har gjort - forholdt mig meget kritisk til hjernedødskriteriet. Tværtimod havde jeg vist, hvordan kroppens brugbarhed opleves som meget meningsfuld for donorpårørende (Jensen 2016). Men noget havde provokeret hende. Det var alligevel for rosenrødt. Jeg ønsker med min antropologiske forskning at undersøge, hvordan hjernedødskriteriet udspiller sig mellem mennesker, snarere end dets biologiske og moralske sandhedsværdi. Desuden er hjernedødens dagsorden old news i feltet. Patienten er død, men kriteriet er skabt med en særlig hensigt om at muliggøre, at velfungerende organer kan tages fra afdøde. Det er ingen hem- 
melighed. Utallige samtaler med neurokirurger og observationer af hjernedøde patienter og hjernedødsundersøgelser har givet mig forståelse af, hvad dødskriteriet betyder, men også af den tvivl, pårørende kan have, og af vigtigheden af tillid og gode relationer i den forbindelse. Men fordi jeg ikke selv personligt betvivler dødskriteriet, og fordi jeg anser det personale, jeg har studeret, som utrolig omsorgsfulde og ikke som sultne organhøstere, kan jeg i min formidling nemt fremstå som ukritisk feltkæledægge $\mathrm{i}$ et internationalt akademisk miljø, der trods øget fokus på relationer og omsorgsarbejde stadig har dybe rødder i en kritisk og politisk medicinsk antropologi, hvor (groft sagt) lægerne var de onde og patienter og pårørende de misforståede lidende subjekter.

Min pointe er, at man i sin forskningsformidling i akademia forventes at indgå i en særlig genre; stå på skuldrene af visse giganter. Vælger man at opbløde veletablerede dikotomier om de gode og de onde, vælger man en mere ukritisk position eller at tilslutte sig andre former for kritik og meninger end den, genren foreskriver, kan det medføre overraskende reaktioner.

Nogle gange er det i den klassiske akademiske formidling, at de største overraskelser opstår. Efter et tidligere feltstudie i USA, hvor jeg kom hjem til Danmark med beretninger om donormødre, der fik medaljer som tak for organdonation og mente, at deres børn levede videre i andre, måtte jeg fra antropologiske kolleger høre de mødre omtalt som „skøre“ eller „,vanvittige“. Og til en konference, hvor jeg som ph.d.-studerende havde stillet mit bedste teoretiske arsenal klar for at tækkes koryfæerne blandt publikum, endte jeg med at svare på helt konkrete spørgsmål om hornhindedonation, mens de nysgerrige helte stønnende tog sig til øjnene. Min pointe er, at som forsker i en forførende og provokerende felt kan du risikere at blive opfattet som talsmand og informatør snarere end antropolog, selv i akademia.

\section{„Så hvordan mener du, vi kan få flere organdonorer?“ - den kort- fattede debattør?}

Som antropologisk forsker mener jeg, man er forpligtet på at formidle sine resultater bredt til danske medier, når man har mulighed for det. Ofte vil journalister efterspørge en klar mening eller position og ikke kun selve resultaterne. Dette kan nemt udfordre den sædvanlige kompleksitet og nuancebegejstring i antropologiske resultater. Antropologen bør overveje ikke om, men hvordan man på forsvarlig vis kan danne en mening, der kan stå frem i debatten, samtidig med at man formidler nuancerne i sine forskningsresultater. De må ud i verden. Men det sker sjældent uden etiske overvejelser. Som organdonationsforsker bliver jeg ofte bedt om at kommentere på forslag om en lovgivningsændring til formodet 
samtykke, eller hvordan Danmark kan løse problemet med organmangel. Jeg bliver bedt om at mene noget. Også noget, jeg ikke altid har forstand på. Jeg mener ikke, at min vigtigste rolle er at mene noget, men jeg stiller gerne op med en mening, fordi det samtidig giver taletid til de stemmer og de nuancer i min forskning, jeg brænder for skal høres.

Mediedialog kan være en stor etisk udfordring, når man fornemmer, at journalister har en særlig dagsorden for forskerens medvirken. Dette oplevede jeg mest udtalt, da jeg var i dialog med journalisten bag den omdiskuterede DRdokumentar „Carina, pigen der ikke ville dø“. DR's hensigt var at lave et program om pårørendes erfaringer med organdonation, men da optagelserne viste et forløb, hvor familien sagde ja til organdonation, men patienten Carina aldrig hjernedøde, skiftede fokus til en usædvanlig og efter min mening urimelig kritisk dokumentar om organlægers intentioner. Umiddelbart efter optagelserne, og før udsendelsen blev sendt, spurgte journalisten mig, om jeg havde mødt familier, der blev manipuleret til at sige ja til organdonation af danske læger. Det havde jeg aldrig mødt, tværtimod, var mit svar, hvorefter han aflyste vores aftalte interview og min medvirken i programmet. Selv om jeg ikke var ked af at stå uden for den dokumentar, viste erfaringen mig, at man som forsker skal være opmærksom på mediernes intentioner. Og det lærte mig, at man bliver valgt til og fra afhængigt af den gældende dagsorden.

Jeg finder ofte mig selv i danske medier gøre mig til stemme for, at der er behov for mere oplysning til befolkningen. Dette er et forskningsbaseret argument, baseret på donorpårørendes fortællinger om behovet for mere indhold i kampagnerne og det neurointensive personales beretninger om, hvor svært det kan være at skulle „starte fra nul“ og informere sagligt om organdonation og hjernedød til familier i chok. Samtidig har jeg med gode kolleger slået fast, at transplantation også er et abstrakt gode, og at meget personale og registrerede donorer praktiserer bevidst uvidenhed, idet de vælger at tro, at transplantation er godt, og ikke nødvendigvis har behov for konkret information (Hoeyer, Jensen \& Olejaz 2015). Så spørgsmålet om information er et komplekst emne. Ofte reduceres det til pointen om, ,at hvis bare man er oplyst om organdonation, så siger man også ja“. Det er ikke helt korrekt, men det kan give spalteplads til mere nuancerede pointer også.

Mediemedvirken er en forhandling, og reduceringen af pointer har ofte noget at gøre med formatet. Man har typisk tre linjer eller 30 sekunder til at sammenflette en brugbar, meningsfuld forskningsbaseret pointe. Og det er en svær kunst. Alternativet er $i k k e$ at medvirke. Og det er der, jeg ser det største etiske problem. Tavsheden må aldrig overvinde angsten for at blive misforstået, forkortet eller simplificeret. Det er essentielt, at antropologer blander sig i de debatter, deres 
felter nu engang afstedkommer. De skriftlige konklusioner på vores resultater er ikke et punktum, men snarere et startskud for andre formidlingsformer.

Spørgsmålet er, om vi som faggruppe og profession kan blive bedre til at støtte vores studerende og vores kolleger i de etiske udfordringer, der opstår, når vores fund formidles og rejser ud i verden.

\section{Litteratur}

Armbruster, Heidi

2010 Introduction: The Ethics of Taking Sides. In: H. Armbruster \& A. Lærke (eds):

Taking Sides. Ethics, Politics, and Fieldwork in Anthropology. Pp. 1-22. New York \& Oxford: Berghahn.

Bell, Catherine

1992 Ritual Theory, Ritual Practice. New York: Oxford University Press.

Hastrup, Kirsten (red.)

2003 Ind i verden. En grundbog i antropologisk metode. København: Hans Reitzels Forlag.

2009 Mellem mennesker. En grundbog i antropologisk forskningsetik. København: Hans Reitzels Forlag.

Hoeyer, Klaus, Anja Marie Bornø Jensen \& Maria Olejaz

2015 Transplantation as an Abstract Good. Practising Deliberate Ignorance in Deceased Organ Donation in Denmark. Sociology of Health and Illness 37(4):578-93.

DOI: $10.1111 / 1467-9566.12211$

Høyer, Klaus Lindgaard, Anja Marie Bornø Jensen \& Sebastian Mohr

2011 På rejse ud i etikkens farlige vådområder. Nordiske Udkast 1-2:104-07.

Jensen, Anja Marie Bornø

2009 Tiltrækkende tragedier. Dilemmaer og sårbarhed i udforskningen af organdonation i USA. I: K. Hastrup (red.): Mellem mennesker. En grundbog i antropologisk

2011 forskningsetik. Side 135-54. København: Hans Reitzels Forlag. Donation in Denmark. København: Ph.D. Series, nr. 69, Institut for Antropologi, Københavns Universitet.

2016 "Make Sure Somebody Will Survive from This": Transformative Practices of Hope among Danish Organ Donor Families. Medical Anthropology Quarterly 30(3):378-94. DOI: 10.1111/maq.12278.

McLean, Athena \& Annette Leibing (eds)

2008 The Shadow Side of Fieldwork. Exploring the Blurred Borders Between Ethnography and Life. Oxford: Blackwell Publishing.

Nordfalk, Francisca, Maria Olejaz, Anja M. Bornø Jensen, Lea Larsen Skovgaard \& Klaus Hoeyer

2016 From Motivation to Acceptability. A Survey of Public Attitudes towards Organ Donation in Denmark. Transplantation Research 5(5):1-8. DOI: 10.1186/s13737016-0035-2.

Wilkinson, Iain \& Arthur Kleinman

2016 A Passion for Society. How We Think about Human Suffering. Oakland: University of California Press. 